\title{
PLASMA PROGESTERONE LEVELS IN PREGNANT AND PSEUDOPREGNANT FERRETS
}

\author{
R. B. HEAP AND J. HAMMOND, JR \\ A.R.C. Institute of Animal Physiology, Babraham, Cambridge, and \\ Department of Applied Biology, University of Cambridge, Downing Street, Cambridge
}

(Received 15th Fanuary 1974)

In the ferret, the life-span and growth of the CL is dependent on pituitary hormones. Hypophysectomy arrests the development of the CL. (Hill \& Parkes, 1932) and causes regression of well-developed CL in pseudopregnant ferrets. Section of the pituitary stalk, however, does not inhibit the function of the CL during the first half of pseudopregnancy (Donovan, 1963). Since ovariectomy results in abortion (McPhail, 1935; Galil, 1965), any placental progesterone secretion is apparently inadequate to sustain the normal pregnant state. There is little evidence that placental or uterine factors influence the life-span of the CL. When the products of conception are removed 22, 27 or 30 days post coitum, the $\mathrm{CL}$ are indistinguishable 8 to 15 days later from those of normal gestation and oestrus recurs normally, about 7 days after the expected time of delivery (Deanesly, 1967). Oestrus also recurs at about the normal time after total hysterectomy (Deanesly \& Parkes, 1933). Hypophysectomy results in abortion even when the operation is carried out in late gestation. In a few animals, however, young were born at the normal time even though the pituitary had been removed between Days 30 and 35 (McPhail, 1935; Galil, 1965).

Pregnancy lasts about 42 days, and the life-span and growth of CL is similar in both pregnant and pseudopregnant ferrets (Hammond \& Marshall, 1930; B. T. Donovan \& J. Oxbrow, personal communication). The purpose of our study was to determine the plasma progesterone concentration in ferrets in order to examine whether the functional activity of the CL, as well as its lifespan and growth, was similar in pregnant and pseudopregnant females. A further aim was to see whether plasma progesterone levels declined 5 to 6 weeks after mating, and whether the plasma oestrogen concentration increased.

Blood samples were taken by cardiac puncture from ferrets under ether anaesthesia or from animals restrained manually. Plasma was separated by centrifugation from heparinized blood samples. The plasma progesterone concentration was determined by a fluorescence assay (Heap, 1964) or a competitive protein-binding technique (CPB) (Challis, Heap \& Illingworth, 1971 ) in those samples collected under anaesthesia, and by radioimmunoassay (Method A, Heap, Gwyn, Laing \& Walters, 1973) in those samples collected from restrained animals. Corpora lutea were dissected from the ovaries of pregnant and pseudopregnant females, stored in A.R. absolute alcohol at $-20^{\circ} \mathrm{C}$, and the steroids were extracted and assayed by gas chromatography (Heap, Holzbauer \& Newport, 1966) and fluorimetry (Heap, 1964). 
Total unconjugated oestrogens were measured by radioimmunoassay (Challis et al., 1971).

Text-figure $1(a)$ shows that the concentration of progesterone in the plasma of pregnant and pseudopregnant ferrets was similar at various times after mating. The concentration showed little change during the first 5 to 6 days after mating, corresponding with the time when the fertilized eggs remain in the oviduct. Thereafter, plasma progesterone levels increased and reached some of their highest values about Day 12, the time when implantation occurs.
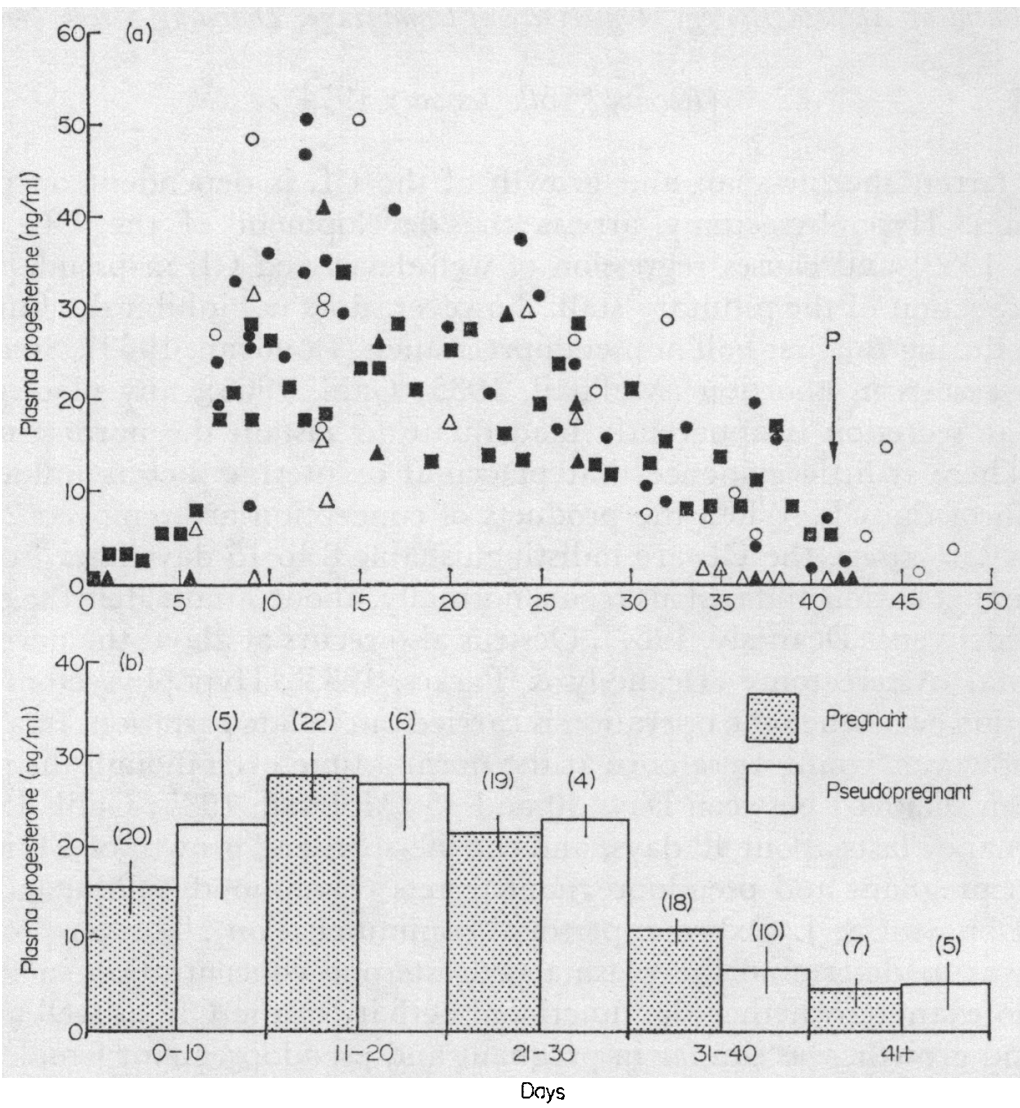

TEXT-FIG. 1. Plasma progesterone concentrations in pregnant and pseudopregnant ferrets. (a) Values in pregnant (solid symbols) and pseudopregnant (open symbols) females measured by fluorimetry $(\boldsymbol{0}, 0)$, competitive protein binding (d) and radioimmunoassay $(\Delta, \Delta)$. (b) Mean values \pm S.E.M. of figures obtained by different assays. Figures in parentheses are the number of observations.

After about Day 15, the concentration decreased steadily and by about Day 42 , low values were recorded in the pregnant and pseudopregnant females. The levels were higher than those found by Blatchley \& Donovan (1972) in hormonally-induced pseudopregnancy.

Evidence of the identity of progesterone in plasma may be deduced from a comparison of values obtained in pregnant females by different analytical techniques. The concentration measured by fluorimetry was similar to that determined by CPB except in mid-pregnancy, the higher values obtained by 
fluorimetry being due possibly to the presence of another progestagen. The plasma progesterone concentration $(\mathrm{ng} / \mathrm{ml})$ on Days 7 to 11 was $24.8 \pm 3.0$ (fluorimetry) and $21.2 \pm 1.6(\mathrm{CPB})$, on Days 12 to 16 was $39.2 \pm 4.2$ and $23.4 \pm 3.0$, on Days 17 to 21 was 34.5 and $23 \cdot 4 \pm 2 \cdot 7$, on Days 22 to 26 was $27 \cdot 0 \pm 4.8$ and $17 \cdot 5 \pm 1 \cdot 8$, on Days 27 to 31 was $17 \cdot 0 \pm 3.8$ and $17 \cdot 7 \pm 3 \cdot 3$, on Days 32 to 36 was 13.0 and $11 \cdot 0 \pm 1 \cdot 7$, and on Days 37 to 41 was $9 \cdot 8 \pm 3 \cdot 5$ and $9 \cdot 8 \pm 2 \cdot 2$. Values obtained by radioimmunoassay were within the range of those recorded by the fluorescence and CPB techniques except that a lower concentration was obtained in late pregnancy and pseudopregnancy. This may be due to the greater accuracy of the more sensitive radioimmunoassay at these concentrations, or to the variation between individual ferrets, which was considerable. Progesterone was not detectable by radioimmunoassay in plasma samples taken from females in oestrus, or after parturition, or from male ferrets.

Total unconjugated oestrogens were not detectable in the majority of plasma samples examined. This finding suggests that the circulating concentration of unconjugated oestrogens is very low, less than $10 \mathrm{pg} / \mathrm{ml}$, as the antiserum used in the assay, SLC-6X, has a broad cross-reaction with several oestrogens including oestradiol-17 $\beta$, oestrone, oestradiol-17 $\alpha$ and oestriol (Challis, Harrison \& Heap, 1973).

The temporal pattern of progesterone levels in pregnant and pseudopregnant ferrets (Text-fig. 1b) resembled that of the growth of the CL which also attained their maximum size between Days 14 to 21 (Hammond \& Marshall, 1930; B. T. Donovan \& I. Oxbrow, personal communication, and also see Heap, Perry \& Challis, 1973). The concentration of progesterone in CL from ovaries removed 13, 21 and 35 days after mating was $24 \cdot 5,40 \cdot 0$ and 23.3 $\mathrm{ng} / \mathrm{mg}$, respectively. Gas chromatographic analysis by a flame ionization detector of extracts of luteal tissue revealed no major peaks other than progesterone.

The results confirm and extend previous observations that the functional activity of the CL of the ferret is similar in pregnancy and pseudopregnancy (Carlson \& Rust, 1969). Progesterone concentrations in peripheral plasma frequently reflect the secretory activity of the CL in those species in which an extra-ovarian source of secretion is negligible. However, in species which produce progesterone-binding globulin (PBG), such as the pregnant guinea-pig and other hystricomorph rodents, the clearance rate of progesterone is reduced and peripheral plasma concentration is increased (Heap \& Illingworth, 1974). No evidence has been found of PBG in pregnant or pseudopregnant ferrets.

The pattern of plasma progesterone levels in the ferret is similar to that in the dog (Christie, Bell, Horth \& Palmer, 1971; Parkes, Bell \& Christie, 1972), the mink, Mustela vison (Møller, 1973a), and the blue fox, Alopex lagopus (Møller, 1973b), but contrasting features are to be found in the absolute plasma progesterone values during pregnancy and pseudopregnancy, and in the early increase in progesterone values after mating. Thus, in the ferret, the values are lower than in the blue fox or pregnant mink, though similar to those in the pseudopregnant mink. The concentration of progesterone in the plasma of mink shows a lag phase after mating and does not increase until after about 10 to 20 days. In the blue fox and dog, progesterone values have already started to increase at the time of mating and show no lag phase. In all 
the carnivores mentioned so far, however, progesterone levels have declined to low values by the time of parturition, or by the end of pseudopregnancy. If the withdrawal of progesterone is a prerequisite for the onset of parturition in these species, it appears that the decline of luteal function is related to the withdrawal of a pituitary luteotrophic stimulus or to the inherent life-span of the CL rather than to the intervention of lytic mechanisms, uterine or fetal in origin. The onset of parturient activity in the ferret occurs at a time when plasma progesterone levels are low, though, as yet, no marked increase in unconjugated oestrogens near term has been detected.

We gratefully acknowledge the help of Dr D. V. Illingworth, Mrs S. Broad, Mr J. Gadsby and Mr A. Henville, and thank Dr B. V. Galdwell, Yale University, for a gift of antiserum raised against oestradiol-17 $\beta$-hemisuccinate conjugated to bovine serum albumin.

\section{REFERENCES}

Blatchley, F. R. \& Donovan, B. T. (1972) Peripheral plasma progestin levels during anoestrus, oestrus and pseudopregnancy and following hypophysectomy in ferrets. F. Reprod. Fert. 31, 331.

Carlson, I. H. \& Rust, C. C. (1969) Plasma progesterone levels in pregnant, pseudopregnant and anoestrous ferrets. Endocrinology, 85, 623 .

Challis, J. R. G., Harrison, F. A. \& Heap, R. B. (1973) The kinetics of oestradiol-17 $\beta$ metabolism in the sheep. F. Endocr. 57, 97.

Challis, J. R. G., Heap, R. B. \& Illingworth, D. V. (1971) Concentrations of oestrogen and progesterone in the plasma of non-pregnant, pregnant and lactating guinea-pigs. F. Endocr. 51, 333.

Ghristie, D. W., Bell, E. T., Horth, C. E. \& Palmer, R. F. (1971) Peripheral plasma progesterone levels during the canine oestrous cycle. Acta endocr., Copenh. 68, 543.

Deanesly, R. (1967) Experimental observations on the ferret corpus luteum of pregnancy. F. Reprod. Fert. 13, 183.

Deanesly, R. \& Parkes, A. S. (1933) The effect of hysterectomy on the oestrous cycle of the ferret. 7. Physiol., Lond. 78, 80.

Donovan, B. T. (1963) The effect of pituitary stalk section on luteal function in the ferret. F. Endocr. $27,201$.

GaliL, A. K. H. (1965) Utero-ovarian interrelations during gestation-endocrine role of the placenta. Ph.D. thesis, University of London.

Hammond, J. \& Marshall, F. H. A. (1930) Oestrus and pseudopregnancy in the ferret. Proc. Roy. Soc. B, 105, 607 .

HEAP, R. B. (1964) A fluorescence assay of progesterone. 7. Endocr. 30, 293.

Heap, R. B., Gwyn, M., Laing, J. A. \& Walters, D. E. (1973) Pregnancy diagnosis in cows; changes in milk progesterone concentration during the oestrous cycle and pregnancy measured by a rapid radioimmunoassay. F. agric. Sci., Camb. 81, 151 .

Heap, R. B., Holzbauer, M. \& NewPort, H. (1966) Adrenal secretion rates of C-19 and C-21 steroids before and after hypophysectomy in the pig and the dog. F. Endocr. 36, 159.

HEAP, R. B. \& ILLINGWORTH, D. V. (1974) The maintenance of gestation in the guinea-pig and other hystricomorph rodents; change in the dynamics of progesterone metabolism and the occurrence of progesterone-binding globulin (PBG). Symp. zool. Soc. Lond. 34 (in press)

Heap, R. B., Perry, J. S. \& Challis, J. R. G. (1973) Hormonal maintenance of pregnancy. In Handbook of Physiology, Section 7, Endocrinology, vol. 2, pp. 217-260. American Physiological Society, Washington D.G.

Hill, M. \& PARKes, A. S. (1932) Studies on the hypophysectomized ferret. III. Effect of post-coitus hypophysectomy on ovulation and the development of the corpus luteum. Proc. $R$. Soc. B, $112,153$.

McPhair, M. K. (1935) Studies on the hypophysectomized ferret. Proc. R. Soc. B, 117, 34.

Moller, O. M. (1973a) The progesterone concentrations in the peripheral plasma of the mink (Mustela vison) during pregnancy. F. Endocr. 56, 121.

Maller, O. M. (1973b) The progesterone concentration in the peripheral plasma of the blue fox (Alopex lagopus) during pregnancy and the oestrous cycle. 7. Endocr. 59, 429.

Parkes, M. F., Bell, E. T. \& Christie, D. W. (1972) Plasma progesterone levels during pregnancy in the beagle bitch. Br. vet. F. 128, xx. 